\title{
Direct and indirect measurements of nitrification and denitrification in the rhizosphere of aquatic macrophytes
}

\author{
Lars Ditlev Mørck Ottosen*, Nils Risgaard-Petersen, Lars Peter Nielsen \\ Institute of Biological Sciences, Department of Microbial Ecology, University of Aarhus, Ny Munkegade, \\ 8000 Aarhus C, Denmark
}

\begin{abstract}
Coupled nitrification-denitrification rates in the rhizosphere of 4 different aquatic macrophytes, Zostera marina, Lobelia dortmanna, Littorella uniflora and Potamogeton pectinatus, were measured by means of both an indirect and a direct ${ }^{15} \mathrm{~N}$ technique. Using the indirect technique we estimated the fraction of $\mathrm{O}_{2}$ excreted by plant roots in the rhizosphere, that was used by coupled nitrification-denitrification. Incubations were carried out in ${ }^{15} \mathrm{NH}_{4}{ }^{+}$amended oxic slurries. This fraction was multiplied with values for root $\mathrm{O}_{2}$ excretion reported in the literature. The indirect technique allowed us to quantify both the oxidation of $\mathrm{NH}_{4}{ }^{+}$to $\mathrm{NO}_{3}$, and the reduction of $\mathrm{NO}_{3}{ }^{-}$to $\mathrm{NH}_{4}{ }^{+}$compared to denitrification. Using the direct technique we estimated coupled nitrification-denitrification from the amount of ${ }^{15} \mathrm{~N}_{2}$ labeled gas that accumulated in intact sediment-plant systems. The 2 techniques recorded similar trends. In these cores ${ }^{15} \mathrm{NH}_{4}{ }^{+}$was added homogeneously to the rhizosphere by perfusion. Denitrification activity in the rhizosphere of $Z$. marina and $P$. pectinatus was low $(1.5$ to $5 \mu \mathrm{mol} N$ $\mathrm{m}^{-2} \mathrm{~h}^{-1}$ ) compared to the activity measured in $L$. dortmanna and $L$. uniflora vegetated sediments $(24$ and $30 \mu \mathrm{mol} \mathrm{N} \mathrm{m} \mathrm{N}^{-2} \mathrm{~h}^{-1}$ ). The variability in denitrification activity was due to differences in the ability of the plants to oxidize the rhizosphere, and difference in the character of sediment $\mathrm{O}_{2}$ and $\mathrm{NO}_{3}{ }^{-}$consumption. This study attempts to clarify how rooted aquatic vegetation affects the sediment nitrogen cycle via oxygen excretion from the roots. Rhizosphere associated nitrogen transformations (coupled nitrification-denitrification) are central to the understanding of nutrient cycling in shallow aquatic ecosystems
\end{abstract}

KEY WORDS: Rooted macrophytes $\cdot$ Rhizosphere $\cdot \mathrm{O}_{2}$ excretion $\cdot$ Coupled nitrification-denitrification

\section{INTRODUCTION}

Submersed macrophytes are unique among rooted aquatic vegetation as they link water column and sediment together with their physical structure. The linkage between sediment and overlying water has important implications for nitrogen cycling in the sediment. Apart from the physical attachment, the sediment provides a source of nutrient supply to the plant. Furthermore, most higher plants in freshwater and marine sediments have a well-developed lacunar system for oxygen supply to the root system. It has previously been shown that a variety of aquatic macrophytes leak oxygen from the roots (Izumi et al. 1980, Sand-Jensen

•E-mail: lars.ottosen@biology.aau.dk et al. 1982). This $\mathrm{O}_{2}$ release may promote coupled nitrification-denitrification in the rhizosphere (Izumi et al. 1980, Flindt 1994, Risgaard-Petersen \& Jensen 1997). but to our knowledge, no studies so far have attempted to measure direct in situ rates of this process. Methods to measure true in situ rates are thus needed to enhance the understanding of nitrogen cycling in the rhizosphere of rooted aquatic macrophytes.

Denitrification in sediments vegetated by rooted macrophytes have, however, been estimated by various indirect techniques. Boon et al. (1986) supplied ${ }^{15} \mathrm{NO}_{3}{ }^{-}$from the water phase to sea grass covered sediments and traced the ${ }^{15} \mathrm{~N}$ contents of the ${ }^{15} \mathrm{NH}_{4}{ }^{+}$, ${ }^{15} \mathrm{NO}_{3}{ }^{-}$, and total $\mathrm{N}$ pools. The authors concluded that denitrification was a relatively minor pathway for $\mathrm{NO}_{3}$ reduction, as compared to dissimilatory reduction of 
$\mathrm{NO}_{3}{ }^{-}$to $\mathrm{NH}_{4}{ }^{+}$(DNRA). In sediment slurries Caffrey \& Kemp (1990) showed that potential rates of nitrification and denitrification were greatly enhanced in Potamogeton perfoliatus and Zostera marina vegetated sediments compared to unvegetated estuarine sediments. Release of gaseous ${ }^{15} \mathrm{~N}_{2}$ from flooded ${ }^{15} \mathrm{NH}_{4}{ }^{+}$ amended soils with aquatic macrophytes provided direct evidence of denitrification coupled to nitrification in the rhizosphere, since such losses could not be detected in soils without plants (Reddy et al. 1989). Using a similar technique, Caffrey \& Kemp (1990) reported enhanced nitrification and denitrification in vegetated estuarine sediments. Christensen \& Sørensen (1986) followed accurnulation of $\mathrm{N}_{2} \mathrm{O}$ after injection of $\mathrm{C}_{2} \mathrm{H}_{2}$ (acetylene) into vegetated lake sediments, and were able to show diel and seasonal variations in denitrification. Flindt (1994) estimated nitrificationdenitrification from mass balance studies of sediments with Z . marina plants. Recently Risgaard-Petersen \& Jensen (1997) applied a double compartment chamber incubated with Lobelia dortmanna vegetated sediment. In this study ${ }^{15} \mathrm{NH}_{4}{ }^{+}$was supplied to the vegetated sediment by diffusion from below. The authors were able to demonstrate that the plants significantly stimulated coupled nitrification-denitrification via $\mathrm{O}_{2}$ release from the root system.

The studies described above increased our understanding of the influence on $\mathrm{N}$-transformations in sediments brought about by rooted macrophytes, but they all seem to hold certain technical limitations. For instance, the addition of ${ }^{15} \mathrm{NO}_{3}{ }^{-}$to the water phase might not be an appropriate technique in vegetated sediments, since ${ }^{15} \mathrm{NO}_{3}{ }^{-}$is consumed before it enters deeper sediment strata (e.g. the rhizosphere), precluding the detection of denitrification. The $\mathrm{C}_{2} \mathrm{H}_{2}$ inhibition technique relies on adequate and stable $\mathrm{NO}_{3}{ }^{-}$pools because $\mathrm{NO}_{3}^{-}$production by nitrification is blocked by $\mathrm{C}_{2} \mathrm{H}_{2}$. Techniques using injection of ${ }^{15} \mathrm{NH}_{4}{ }^{+}$into the sediments suffer from a heterogeneous ${ }^{15} \mathrm{~N}$-enrichment of the ${ }^{15} \mathrm{NH}_{4}{ }^{+}$pool which might cause an underestimation of actual denitrification rates (Boast et al. 1988). Although this drawback was overcome by Risgaard-Petersen \& Jensen (1997), their experimental design is very time consuming and difficult.

In this study we introduce 2 simple methods for determining coupled nitrification-denitrification in the rhizosphere of aquatic macrophytes. Both of the methods are easy to handle and can be applied as a monitoring tool in laboratories with access to mass spectrometry.

With one of the methods we couple known literature values of oxygen excretion over the root surface (e.g. Sand-Jensen et al. 1982), with measurements of the contribution of nitrification to oxygen consumption, and measurements of the contribution of denitrifica- tion to $\mathrm{NO}_{3}{ }^{-}$reduction. Coupled nitrification-denitrification can then be calculated as the product of these values. This method thus yields information about both nitrification activity and the nature of $\mathrm{NO}_{3}^{-}$reduction.

With the other method we measure coupled nitrification-denitrification activity directly using a ${ }^{15} \mathrm{~N}$ perfusion method in intact plant-sediment systems. This method has been used in a previous study of the $\mathrm{N}$ cycle in Zostera marina vegetated sediment (RisgaardPetersen et al. 1998). The technique enables a homogenous distribution of the tracer $\left({ }^{15} \mathrm{NH}_{4}{ }^{+}\right)$in the rhizosphere, and allows identification of the vertical distribution of the coupled denitrification activity. In the present study we expand the application of the method to both freshwater (Lobelia dortmanna, Littorella uniflora, Potamogeton pectinatus) and marine macrophytes ( $Z$. marina) and furthermore present some fundamental tests of the method.

Using these 2 methods in concert, it is possible to evaluate the importance of aquatic macrophytes regarding nitrogen removal in sediments, via coupled nitrification-denitrification in the rhizosphere, and to elucidate the importance of nitrification and denitrification relative to other $\mathrm{O}_{2} / \mathrm{NO}_{3}{ }^{-}$consuming dissimilatory processes.

\section{MATERIALS AND METHODS}

Study area and sampling procedures. Marine sediment cores were collected from a Zostera marina vegetated bed, and from adjacent bare areas at 2 different sites. Site 1 was located at Løgstør bredning, Limfjorden, Denmark, a eutrophic shallow water estuary with patchy populations of eelgrass ( $Z$. marina). At the sampling site (Aggersund) eelgrass covers 2 to $5 \%$ of the sea floor from 0 to $1 \mathrm{~m}$ depth. The coverage decreases with increasing depth and depth limit for the plants is $-4 \mathrm{~m}$. The sediment is sandy with a porosity of 0.69 . Site 2, the exposed sampling site, was located in the Bight of Aarhus, Aarhus, Denmark. At the sampling site (Vejlby Fed) Z. marina covers $60 \%$ of the sea floor from 0.4 to $5.2 \mathrm{~m}$.

Freshwater plants (Lobelia dortmana and Littorella uniflora) and adjacent bare sediment were collected from Lake Hampen. For a description of the lake see Christensen \& Serensen (1986). Cores with Potamogeton pectinatus were collected from the shallow eutrophic Lake Stigsholm (Schriver et al. 1995).

Intact sediment cores, with and without plants, were collected in $50 \mathrm{~cm}$ clear Plexiglas tubes with an inner diameter of $10 \mathrm{~cm}$. The cores were transported to the laboratory within $1 \mathrm{~h}$ and placed in open reservoirs with in situ water, held at in situ temperature. The cores were exposed to a $12 \mathrm{~h}$ light/dark cycle and light 
was supplied by a Halogen lamp (irradiance: $150 \mu \mathrm{mol}$ photons $\mathrm{m}^{-2} \mathrm{~s}^{-1}$ ). During this preincubation the water column above the sediment was purged with atmospheric air supplied from an aquarium pump.

Additionally, a large eelgrass sod $(50 \times 80 \mathrm{~cm})$ was collected at Vejlby Fed. In the laboratory the plants were kept actively growing in an aquarium during the experimental period. The sediment in that aquarium was exposed a $12 \mathrm{~h}$ light/dark cycle. Light was supplied as above. The sod was used for measurements of growth and porewater $\mathrm{NO}_{3}{ }^{-}$concentrations.

Slurry incubations (indirect method). Triplicates of bare Zostera marina and Lobelia dortmanna vegetated sediment cores were sliced in depth intervals of $1 \mathrm{~cm}$. Cores with plants were sliced until below the dense part of the rhizosphere $(\sim 7 \mathrm{~cm}$ below the sediment surface). From each slice of sediment, 2 different incubations were made: an oxic incubation with ${ }^{15} \mathrm{NH}_{4}{ }^{+}$and an anoxic with ${ }^{15} \mathrm{NO}_{3}{ }^{-}$. Both of these incubations were performed in $12 \mathrm{ml}$ glass vials (Exetainer, Labco, High Wycombe, UK). The oxic incubations were performed to estimate the contribution of coupled nitrificationdenitrification to the $\mathrm{O}_{2}$ consumption of the sediment. The vials were incubated with $2 \mathrm{ml}$ of sediment and $10 \mathrm{ml}$ oxygen saturated in situ water with ${ }^{15} \mathrm{NH}_{4}{ }^{+}$ (500 $\mu \mathrm{M}$ ). During the incubation $\mathrm{O}_{2}$ was consumed and ${ }^{15} \mathrm{NO}_{3}{ }^{-}$was produced from the added ${ }^{15} \mathrm{NH}_{4}{ }^{+}$. When the $\mathrm{O}_{2}$ was depleted, the produced ${ }^{15} \mathrm{NO}_{3}{ }^{-}$was reduced by denitrification or nitrate ammonification. The products of denitrification $\left({ }^{15} \mathrm{~N}_{2}\right)$ could then be measured by mass spectrometry. These slurry incubations thus indicated the fraction of oxygen in the slurry that was consumed by coupled nitrification-denitrification. Only the end product $\mathrm{N}_{2}$ was measured, so in order to quantify nitrification it was necessary to know how much of the produced nitrate was denitrified.

The anoxic incubations with ${ }^{15} \mathrm{NO}_{3}{ }^{-}$ were performed to determine the contribution of denitrification to $\mathrm{NO}_{3}{ }^{-}$reduction. The vials were incubated with $2 \mathrm{ml}$ sediment and $10 \mathrm{ml}$ anoxic in situ water (purged with $\mathrm{N}_{2}$ for at least $30 \mathrm{~min}$ ) with ${ }^{15} \mathrm{NO}_{3}^{--}$added to a final concentration of $50 \mu \mathrm{M}$. All of the vials for both types of incubation were placed on an agitator and incubated in the dark at room temperature $\left(20^{\circ} \mathrm{C}\right)$ for $24 \mathrm{~h}$.

Hereafter the samples were analyzed for ${ }^{15} \mathrm{~N}_{2}$. These anoxic slurry incubations indicated the fraction of produced $\mathrm{NO}_{3}^{-}$that was denitrified. By knowing both the coupled nitrification-denitrification (that is, $\mathrm{NH}_{4}{ }^{+}$to $\left.\mathrm{N}_{2}\right)$, and denitrification $\left(\mathrm{NO}_{3}{ }^{-}\right.$to $\left.\mathrm{N}_{2}\right)$, the nitrification could indirectly be estimated. It was assumed that the ratio in the slurries between total oxygen consumption and oxygen consumption by nitrification resembled the true in situ ratio in the rhizosphere, and that the ratio between total $\mathrm{NO}_{3}{ }^{-}$consumption and $\mathrm{NO}_{3}{ }^{-}$consumption by denitrification also resembled the true in situ ratio. Under these assumptions it was possible to multiply the fractions calculated from the slurry incubations, with a known root oxygen excretion rate from plants in a given vegetated sediment, and then estimate the rhizosphere associated coupled nitrification-denitrification on a $\mathrm{m}^{2}$ base.

Perfusion experiment (direct method). Direct measurements of coupled nitrification-denitrification in bare (marine and freshwater), Zostera marina, Lobelia dortmanna, Littorella uniflora, and Potamogeton pectinatus vegetated sediments were conducted with the ${ }^{15} \mathrm{NH}_{4}{ }^{+}$perfusion technique. The measurements were performed with 3 replicates from each type of sediment.

The rubber stoppers at the bottom of the Plexiglas tubes containing the sediment were replaced with plastic stoppers with circular canals joining in a single outlet (Fig. 1). The outlet was connected via a flask to a vacuum pump, and the porewater was drawn into the flask. A nylon filter was placed between the sediment and the plas-

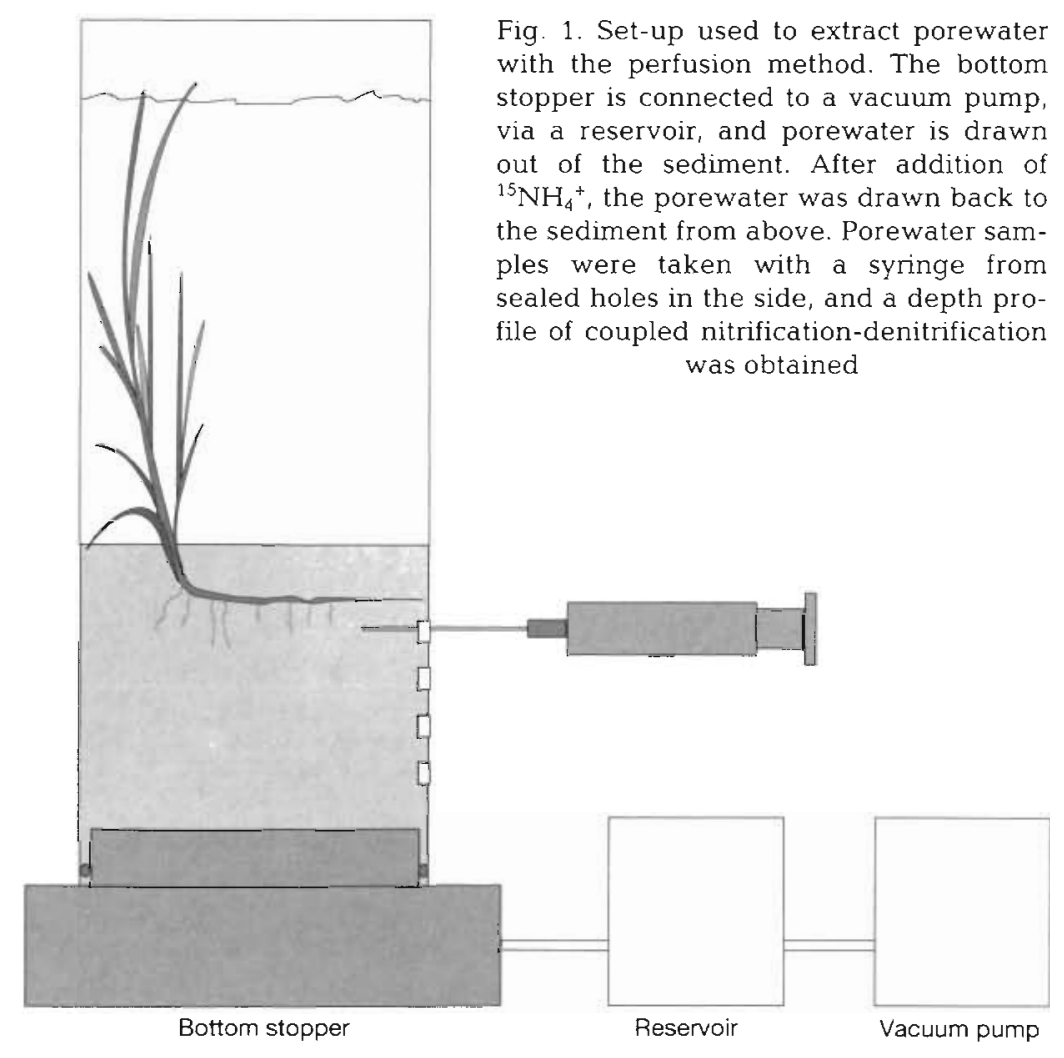


tic stopper to avoid loss of sediment during porewater extraction. Contamination of the rhizosphere with oxygen was avoided by purging the water column above the sediment with $\mathrm{N}_{2}$ for $10 \mathrm{~min}$, before extracting the porewater. $500 \mu \mathrm{mol}{ }^{1.5} \mathrm{NH}_{4}{ }^{+} \mathrm{l}^{-1}$ was added to the extracted porewater, which was then purged with $\mathrm{N}_{2}$. The remaining water column above the sediment was removed, and the ${ }^{15} \mathrm{NH}_{4}{ }^{+}$-enriched porewater was gently added to the core, and drawn into the sediment from above. Then the water column above the sediment was replenished with fresh in situ water.

The vegetated, ${ }^{15} \mathrm{~N}$-enriched sediment was incubated for $6 \mathrm{~h}$ at $12^{\circ} \mathrm{C}$ under a Halogen lamp (150 $\mu \mathrm{mol}$ photons $\mathrm{m}^{-2} \mathrm{~s}^{-1}$ ). At the beginning and at the end of the incubation, porewater samples were collected from the cores with a gas-tight syringe, equipped with a hypodermic needle. The sampling was done at depth intervals of $1 \mathrm{~cm}$ through a vertical row of small silicon sealed holes $(\varnothing=3 \mathrm{~mm})$. Porewater samples were collected all across the sediment core, by pulling the syringe gently outwards while filling it. This procedure ensured a representative sample from each depth. The porewater samples were transferred to helium flushed $5 \mathrm{ml}$ glass vials (Exetainer, Labco, High Wycombe, UK) with $300 \mu l 7 \mathrm{M} \mathrm{ZnCl}_{2}$ added to inhibit microbial activity. The samples were stored for less than $5 \mathrm{~d}$ before they were analyzed for ${ }^{15} \mathrm{~N}_{2}$.

To verify that no water from the water column was drawn into the sediment during the porewater sampling procedure, and that the sampling technique allowed us to see a discrete zonation of the $\mathrm{N}_{2}$ production activity in the sediment, test sampling of the porewater was performed with $\mathrm{Br}^{-}$added to the water column. The porewater sampling was performed as described above, and the samples were transferred to polyethylene tubes and frozen for later determination of the $\mathrm{Br}^{-}$concentration.

To verify that ${ }^{15} \mathrm{NH}_{4}{ }^{+}$was not exhausted during the incubation, porewater samples were collected at depths of 2,5 and $8 \mathrm{~cm}$ at the beginning and end of the incubations, as described above. The samples were immediately frozen $\left(-20^{\circ} \mathrm{C}\right)$ for later determination of the ${ }^{15} \mathrm{NH}_{4}{ }^{+}$concentration.

Oxygen excretion from the roots, and thus coupled nitrification-denitrification, can only be expected to occur if experimental plants are actively growing. Growth of the eelgrass plants in cores similar to the incubation cores was therefore measured with the leafmarking technique (Sand-Jensen 1975). The meristem of each shoot was pierced with a hypodermic needle just above the leaf sheet. Leaf growth was measured from the displacement of marks on the young leaves relative to marks on the older leaves (leaves 4 to 6 ).

Samples for $\mathrm{NO}_{3}{ }^{-}$determinations in the porewater of the eelgrass sod were collected with syringes and a sipper. The sipper was constructed from a rigid tube with a series of membrane covered holes in the side, which could be opened at various depths, thus allowing porewater to ooze in (J. W. Hanson unpubl.). The sipper was inserted into the sediment and redrawn after $\sim 10 \mathrm{~min}$. The porewater was analyzed for $\mathrm{NO}_{3}{ }^{-}$ within $5 \mathrm{~min}$.

Analysis. Dinitrogen gas was extracted from the water samples in the glass vials by introducing a $1 \mathrm{ml}$ helium headspace and then shaking vigorously for $1 \mathrm{~min}$. Sub samples of the headspace gas $(250 \mu \mathrm{l})$ were injected into a gas chromatograph in line with the isotope ratio mass spectrometer (Sira Series II, VG Isotech, Middlewich, Cheshire, UK) and analyzed for ${ }^{28} \mathrm{~N}_{2},{ }^{29} \mathrm{~N}_{2}$ and ${ }^{30} \mathrm{~N}_{2}$ as described by Nielsen (1992).

Bromide was determined on a HPLC system (Sycam, Glinching, Germany) equipped with a UV detector (220 nm, model spectromoniter 3200, Thermoseparation products, Riviera Beach, Florida) and an anion column $(4 \times 250 \mathrm{~mm}$ aniontrenn LCA4, Sycam) held at $60^{\circ} \mathrm{C}$. The eluent was $\mathrm{NaCl}(40 \mathrm{mM})$, with a flow rate of $1.5 \mathrm{ml} \mathrm{s}^{-1}$.

${ }^{15} \mathrm{NH}_{4}{ }^{+}$was determined using the ${ }^{15} \mathrm{NH}_{4}{ }^{+}$microdiffusion assay (Risgaard-Petersen \& Rysgaard 1995).

$\mathrm{NO}_{3}{ }^{-}$was determined on a Flow Injection Analyzer (Tecator, Höganäss, Sweden), using the sulphanilamide-napthylene-diamide method after reduction of $\mathrm{NO}_{3}{ }^{-}$to $\mathrm{NO}_{2}{ }^{-}$by a cadmium column (Grasshoff et al. 1983).

Calculations. The overall amounts of $\mathrm{N}_{2}$ produced by denitrification in the slurries and in the ${ }^{15} \mathrm{~N}$ perfused sediments were calculated from the produced ${ }^{29} \mathrm{~N}_{2}$ and ${ }^{30} \mathrm{~N}_{2}$. The amount of gas produced from denitrification based on ${ }^{15} \mathrm{NO}_{3}{ }^{-}$was calculated as:

$$
D_{15}=\left({ }^{29} \mathrm{~N}_{2}\right)+2\left({ }^{30} \mathrm{~N}_{2}\right)
$$

The amount of gas produced by denitrification of ${ }^{14} \mathrm{NO}_{3}{ }^{-}\left(D_{14}\right)$ was calculated using the principles of isotope pairing (Nielsen 1992):

$$
D_{14}=\frac{{ }^{29} \mathrm{~N}_{2}}{2^{30} \mathrm{~N}_{2}} \times D_{15}
$$

In the slurries incubated with ${ }^{15} \mathrm{NH}_{4}{ }^{+}$and $\mathrm{O}_{2}$, the amounts of produced $\mathrm{N}_{2}\left(D_{14}+D_{15}\right)$ was divided with the amounts of $\mathrm{O}_{2}$ consumed during the incubation (corresponding to the initial amount of $\mathrm{O}_{2}$, since $\mathrm{O}_{2}$ was completely exhausted during the incubation).

$$
R_{\text {nit-denit }}=\frac{\text { produced mol N }}{4 \times \text { consumied mol O }}
$$

This ratio $\left(R_{\text {nit-denit }}\right)$ is equivalent to the ratio between coupled nitrification-denitrification and sedimentary $\mathrm{O}_{2}$ consumption. In the slurries incubated with ${ }^{15} \mathrm{NO}_{3}{ }^{-}$ the amounts of produced ${ }^{15} \mathrm{~N}_{2}\left(D_{15}\right)$ was divided with the amounts of ${ }^{15} \mathrm{NO}_{3}{ }^{-}$consumed (corresponding to the 
initial amount of ${ }^{15} \mathrm{NO}_{3}{ }^{-}$, since $\mathrm{NO}_{3}{ }^{-}$was completely exhausted during the incubation).

$$
R_{\text {denit }}=\frac{\text { produced mol }{ }^{30} \mathrm{~N}_{2}}{2 \times \text { consumed mol }{ }^{15} \mathrm{NO}_{3}{ }^{-}}
$$

This ratio $\left(R_{\text {denit }}\right)$ corresponds to the ratio between denitrification and $\mathrm{NO}_{3}{ }^{-}$reduction.

To calculate the contribution of nitrification to sedimentary $\mathrm{O}_{2}$ consumption $\left(R_{\text {nIt }}\right), R_{\text {nIt-denit }}$ was divided with $R_{\text {denit }}$.

$$
R_{\text {nit }}=\frac{R_{\text {nit-denit }}}{R_{\text {denit }}}
$$

Volume-specific denitrification activity in the ${ }^{15} \mathrm{NH}_{4}{ }^{+}$ amended intact cores was calculated at each depth from changes in $D_{14}$ (and $D_{15}$ ) during the $6 \mathrm{~h}$ incubation period. The volume-specific activities were integrated with depth to give the area based denitrification rate.

\section{RESULTS}

\section{Slurry incubations (indirect method)}

Less than $3 \%$ of the oxygen consumption of the eelgrass rhizosphere was due to nitrification (Fig. 2A). About $10 \%$ of the ${ }^{15} \mathrm{NO}_{3}{ }^{-}$added to sediments from the eelgrass rhizosphere could be detected as ${ }^{15} \mathrm{~N}$ labeled $\mathrm{N}_{2}$. Variation among the different depths was not statistically significant (ANOVA, p $<0.05$ ). Both the share of nitrification in total $\mathrm{O}_{2}$ demand and the recovery of added ${ }^{15} \mathrm{NO}_{3}{ }^{-}$as $\mathrm{N}_{2}$ were lower than values for the unvegetated marine sediment.

Nitrification accounted for a relatively high fraction of the $\mathrm{O}_{2}$ demand ( 50 to $60 \%$ in the upper $2 \mathrm{~cm}$ ) of the Lobelia dortmanna rhizosphere, when compared to the eelgrass rhizosphere. Also a much larger percentage (20 to $80 \%$ ) of the added ${ }^{15} \mathrm{NO}_{3}{ }^{-}$was denitrified (Fig. 3B). Except for the upper $1 \mathrm{~cm}$ of the sediment, there was no clear difference between activities obtained in the vegetated and the unvegetated lake sediment.

\section{Coupled nitrification-denitrification in intact sediment}

The measured bromide concentrations in porewater drawn out with a syringe provide evidence that water from the water column was not mixed with porewater during sampling. Bromide concentrations never exceeded $1 \mathrm{mM}$ (natural background in the seawater used) below $1 \mathrm{~cm}$ depth (Fig. 4). It is therefore also reasonable to separate depth activities, as porewater from above and below layers during sampling from the perfusion cores is only slightly mixed during sampling.
There was excess of ${ }^{15} \mathrm{NH}_{4}{ }^{+}$in the rhizosphere during the entire incubation. The average concentration immediately after addition of ${ }^{15} \mathrm{NH}_{4}{ }^{+}$in the cores was $384.6 \mu \mathrm{M}(\mathrm{n}=3, \mathrm{SE}=50.0)$. At the end of the incubations average concentration was not significantly different $(328 \mu \mathrm{M}, n=3, \mathrm{SE}=94.6)$.

Depth-integrated rates of coupled nitrification-denitrification in the rhizosphere of the eelgrass vegetated sediment was $1.33 \pm 0.24 \mu \mathrm{mol} \mathrm{N} \mathrm{m}^{-2} \mathrm{~h}^{-1}$ (integrated value for Fig. 5A). Coupled nitrification-denitrification in the unvegetated marine sediment was $4.22 \pm$ $1.17 \mu \mathrm{mol} \mathrm{N} \mathrm{m} \mathrm{N}^{-2} \mathrm{~h}^{-1}$. Rates were not statistically different in bare and vegetated marine sediment ( $t$-test, hypothesized mean difference $=0, p \gg 0.05$ )

In contrast to the eelgrass vegetated sediments the activity profiles in the Littorella uniflora (integrated value: $\left.30.1 \pm 7.67 \mu \mathrm{mol} \mathrm{N} \mathrm{m}^{-2} \mathrm{~h}^{-1}\right)$ and Lobelia dortmanna (24.6 $\mu \mathrm{mol} \mathrm{N} \mathrm{m}^{-2} \mathrm{~h}^{-1}$ ) vegetated sediments showed a clear stimulation of the coupled nitrificationdenitrification compared to the bare sediment (Fig. 6) ( $t$-test, hypothesized mean difference between bare and vegetated lake sediment $=0, p<<0.05$ ). Highest activity was found in the 1 to $3 \mathrm{~cm}$ depth interval, which is coincident with the most dense part of the rhizosphere. Denitrification rates for Potamogeton perfoliatus were somewhat lower, $5.40 \pm 2.41 \mu \mathrm{mol} \mathrm{N} \mathrm{m} \mathrm{N}^{-2}$ $\mathrm{h}^{-1}$. Results are shown in Fig. 6C.

Depth-integrated rates of coupled nitrification-donitrification were thus lowest in the Zostera marina sediments (Fig. 7). The activities in these sediments were not significantly different from the activity obtained in the corresponding bare sediments. Potamogeton perfoliatus vegetated sediments were also subject to a low stimulation of coupled nitrification-denitrification. In contrast, coupled nitrification-denitrification activity in the Lobelia dortmanna and Littorella uniflora exceeded the activity in the unvegetated sediments by a factor of $>100$, suggesting that the presence of these plants promotes a clear stimulation of the processes.

\section{DISCUSSION}

Coupled nitrification-denitrification activity in the vegetated sediment can be calculated from the data obtained with the slurry method. From these data we know the ratio between sediment $\mathrm{O}_{2}$ consumption and coupled nitrification-denitrification. Multiplying this value with values for root $\mathrm{O}_{2}$ release gives an estimate of the rate of coupled nitrification-denitrification in the rhizosphere of the plants. For the Zostera marina vegetated sediment, $2 \%$ of the sediment $\mathrm{O}_{2}$ demand in the rhizosphere could be attributed to nitrification, and $10 \%$ of the $\mathrm{NO}_{3}{ }^{-}$reduction activity could be attributed to denitrification. The ratio between coupled nitrifica- 
A. Eelgrass sediment. Percent of $\mathrm{O}_{2}$ consumed by nitrification

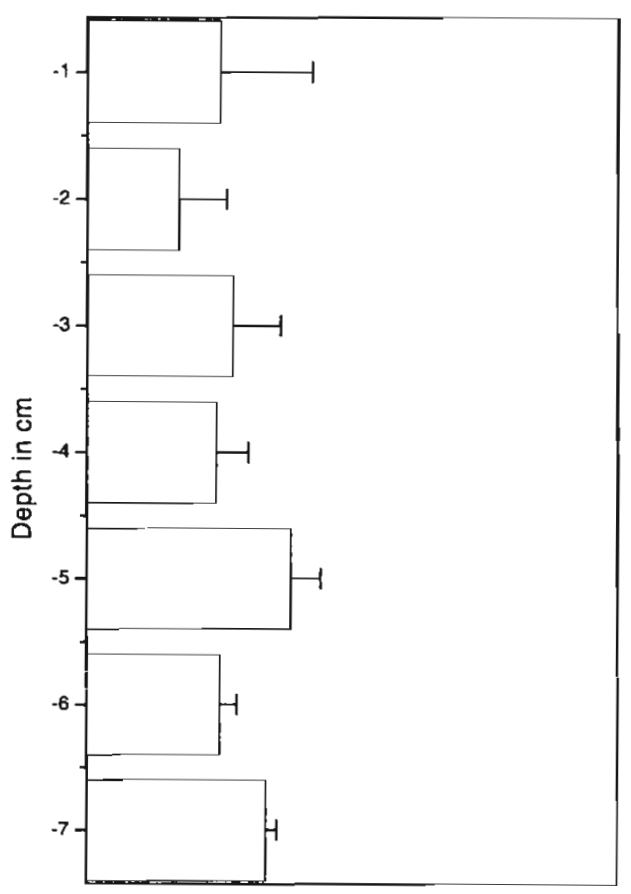

C. Bare sediment. Percent of $\mathrm{O}_{2}$ consumed by nitrification

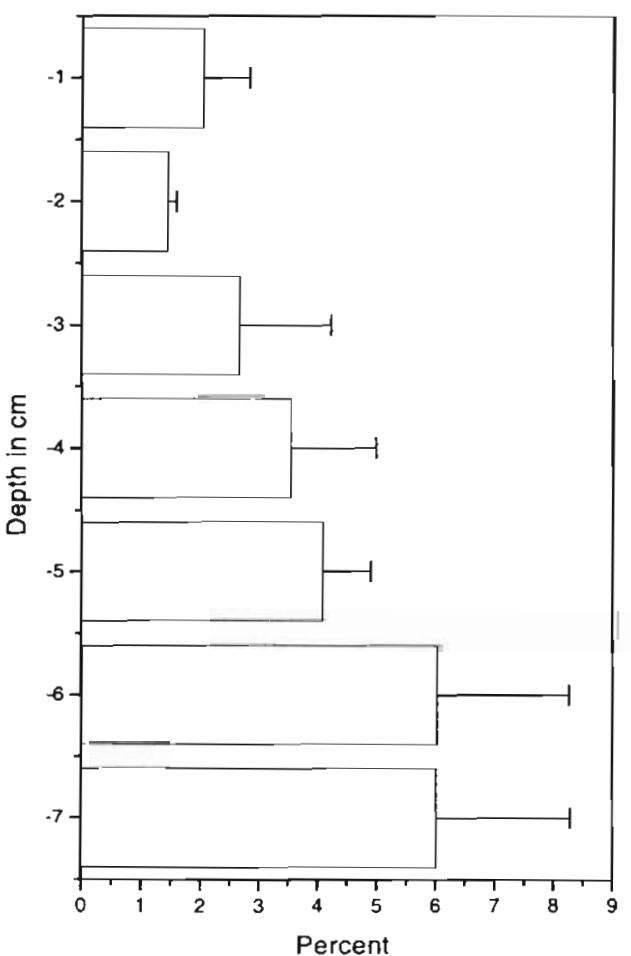

B. Percentage of added $\mathrm{NO}_{3}$. denitrified, eelgrass sediment

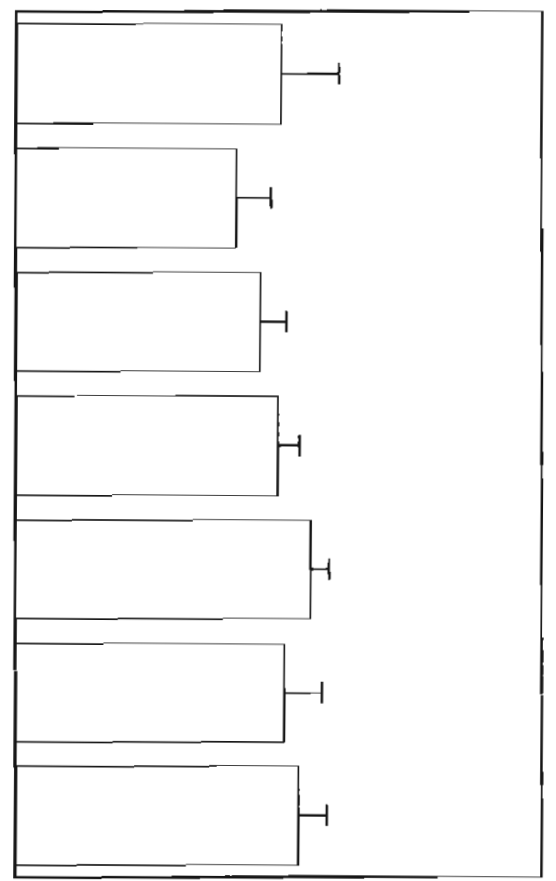

D. Percentage of added $\mathrm{NO}_{3}$ denitrified, bare sediment

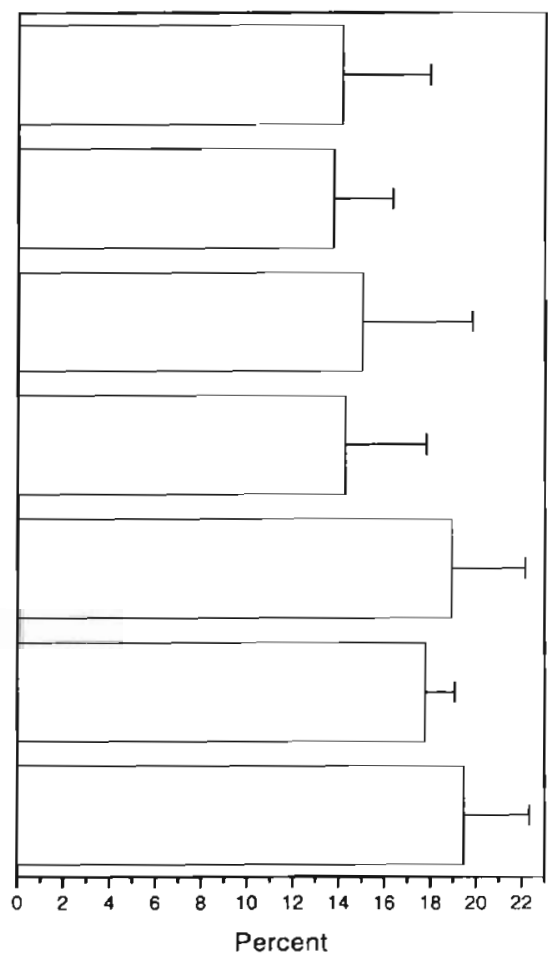

Fig. 2. Data for slurry incubations of marine sediments: $(A, C)$ results for the $\mathrm{NH}_{4}{ }^{+}$ incubations are given in percent oxygen consumed by coupled nitrification-denitrification in the incubation exetainers; $(B, D)$ results for the $\mathrm{NO}_{3}^{-}$incubations show the percentage of the $\mathrm{NO}_{3}{ }^{-}$added to the exetainers that is denitrified under anoxic conditions

tion-denitrification and $\mathrm{O}_{2}$ consumption was therefore $2 / 1000$ Reported rates of $\mathrm{O}_{2}$ release from $Z$. marina roots range between 500 umol m $\mathrm{m}^{-2} \mathrm{~h}^{-1}$ (Sand-Jensen et al. 1982), $5350 \mu \mathrm{mol} \mathrm{m}^{-2} \mathrm{~h}^{-1}$ (Izumi et al. 1980) and 4000 to $6000 \mu \mathrm{mol} \mathrm{m} \mathrm{m}^{-2} \mathrm{~h}^{-1}$ (Caffrey \& Kemp 1991). Rates of coupled nitrification-denitrification in the eelgrass rhizosphere range therefore between 1 and $12 \mu \mathrm{mol} \mathrm{N}$ $\mathrm{m}^{-2} \mathrm{~h}^{-1}$, if the $\mathrm{O}_{2}$ consumption and denitrification pattern demonstrated with the slurry incubations/indirect method are assumed to represent in situ conditions. The manipulation of the sediment performed during the slurry incubations may however introduce some bias in relation to in situ environment. It is possible that some spontaneous oxidation of sulfide in the slurries will tend to exaggerate that $\mathrm{O}_{2} \operatorname{sink}$, and thus lead to an underestimation of the nitrification activity. However, results from the perfusion measurements indicate that this may not be a fatal source of error for the method in this case, as estimated coupled nitrificationdenitrification rates for both methods are close.

A similar calculation as above of the activity in the Lobelia dortmanna vegetated sediment suggests that coupled nitrificationdenitrification activity is approximately $93 \mu \mathrm{mol} \mathrm{N} \mathrm{m}^{-2} \mathrm{~h}^{-1}$, when a rate $\mathrm{O}_{2}$ release of $2060 \mu \mathrm{mol}$ $\mathrm{m}^{-2} \mathrm{~h}^{-1}$ is applied (Pedersen et al. 1995).

Using the slurry incubations we obtained information about the nitrification potential in relation to a given $\mathrm{O}_{2}$ excretion. Denitrification of $\mathrm{NO}_{3}{ }^{-}$produced by nitrification could also be determined in relation to total $\mathrm{NO}_{3}$ reduction. For bare marine sediment and eelgrass sediment in this study, about 10 to $15 \%$ of the produced $\mathrm{NO}_{3}{ }^{-}$was denitrified (Fig. 2B,D). A larger fraction of 
the $\mathrm{NO}_{3}{ }^{-}$pool was thus reduced to other substances than $\mathrm{N}_{2}$. One possible explanation is that $\mathrm{NO}_{3}{ }^{-}$ is reduced to $\mathrm{NH}_{4}{ }^{+}$via dissimilatory nitrate reduction to ammonium (DNRA). One study indicates that 13 to $28 \%$ of added $\mathrm{NO}_{3}{ }^{-}$is reduced to $\mathrm{NH}_{4}{ }^{+}$in eelgrass vegetated sediments (Boon et al. 1986). This seems likely in an environment where limitation of electron acceptors possibly restricts metabolism (Tiedje et al. 1982). Assimilation in benthic microbes could also be of significant importance (Boon et al. 1986). Caffrey \& Kemp (1990) found that about $80 \%$ of $\mathrm{NO}_{3}{ }^{-}$in the rhizosphere of Zostera marina was assimilated, or reduced to other substances than $\mathrm{N}_{2}$, and $20 \%$ was denitrified.

For Zostera marina both the slurry incubations and direct perfusion measurements gave coupled nitrification-denitrification rates of about $1 \mu \mathrm{mol} \mathrm{N} \mathrm{m}^{-2}$ $\mathrm{h}^{-1}$. These are low rates compared to previous estimates indicating values of about $64.5 \mu \mathrm{mol}$ $\mathrm{N} \mathrm{m}{ }^{-2} \mathrm{~h}^{-1}$ based on a mass balance (Flindt 1994), and 67 to $209 \mu \mathrm{mol} \mathrm{N} \mathrm{m}^{-2} \mathrm{~h}^{-1}$ based on potential nitrogen transformation rates (Caffrey \& Kemp 1990). Measurements of $Z$. marina bed porewater nitrate in this study support the calculated low values of nitrification and denitrification. In all porewater samples measured, the $\mathrm{NO}_{3}{ }^{-}$concentration below the sediment surface was $<1 \mu \mathrm{M}$. This is indeed not the case in other $Z$. marina populated sediments, with $\mathrm{NO}_{3}{ }^{-}$concentration $\sim 10 \mu \mathrm{M}$ (Boon et al. 1986, Caffrey \& Kemp 1990, Flindt 1994). Spatial difference and seasonal variation could be important in explaining variation in nitrogen transformation rates among the discussed studies, but also the reducing capacity of the sediment could possibly influence the nitrogen transforma-

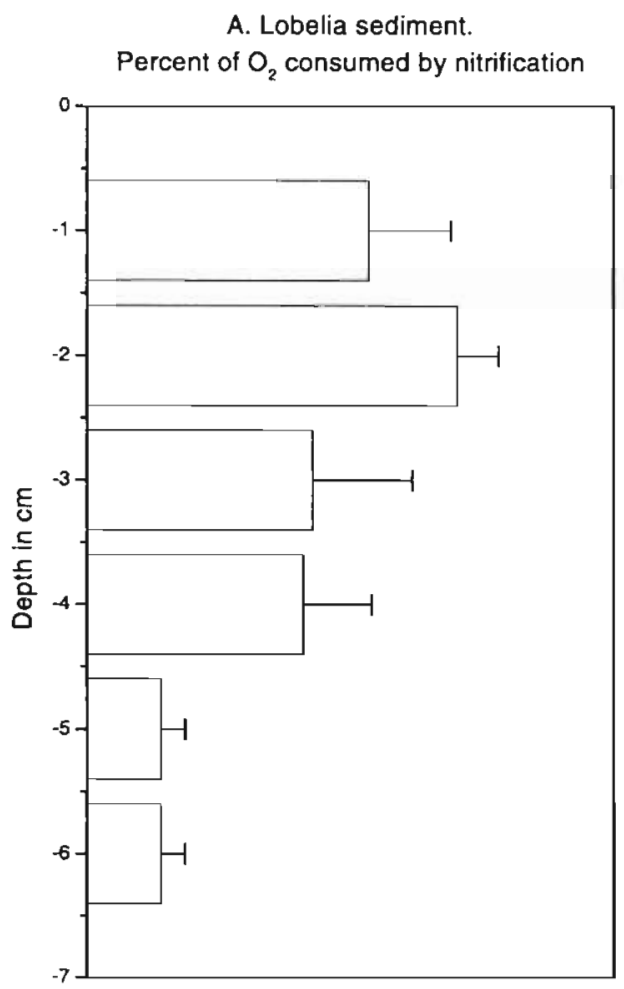

B. Lobelia sediment.

Percentage of added $\mathrm{NO}_{3}$ denitrified,

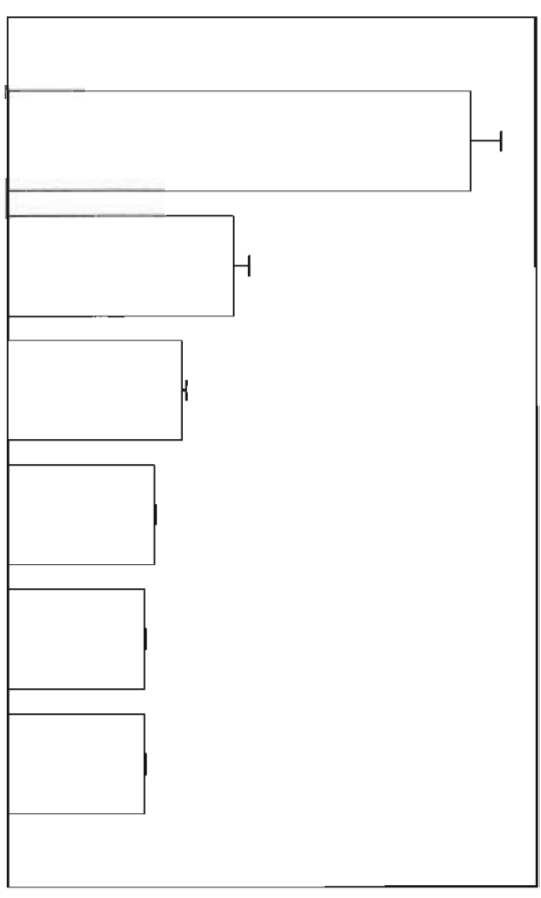

C. Bare sediment. Percent of $\mathrm{O}_{2}$ consumed by nitrification

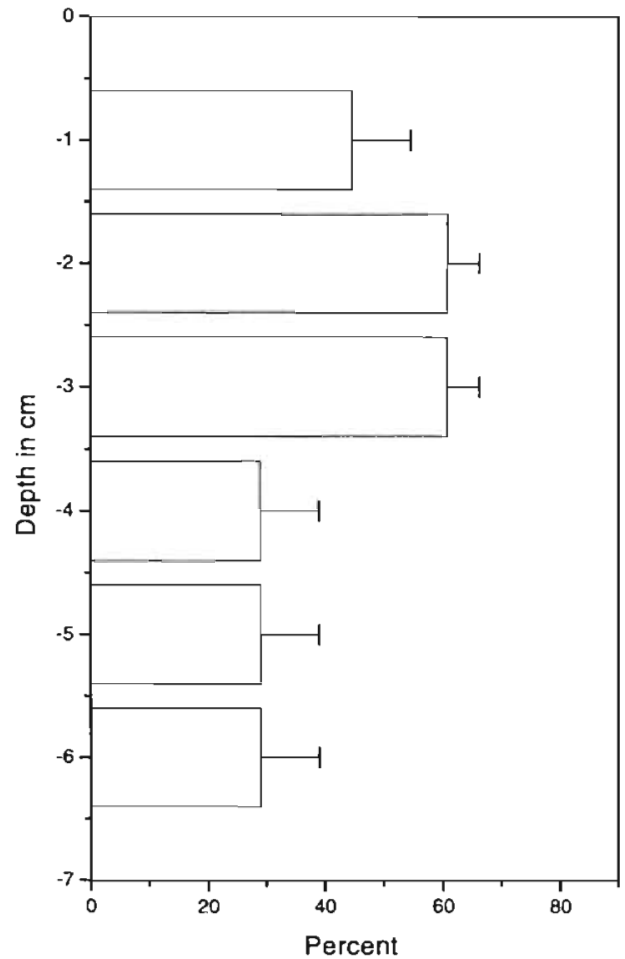

D. Percentage of added $\mathrm{NO}_{3}$ denitrified, bare sediment

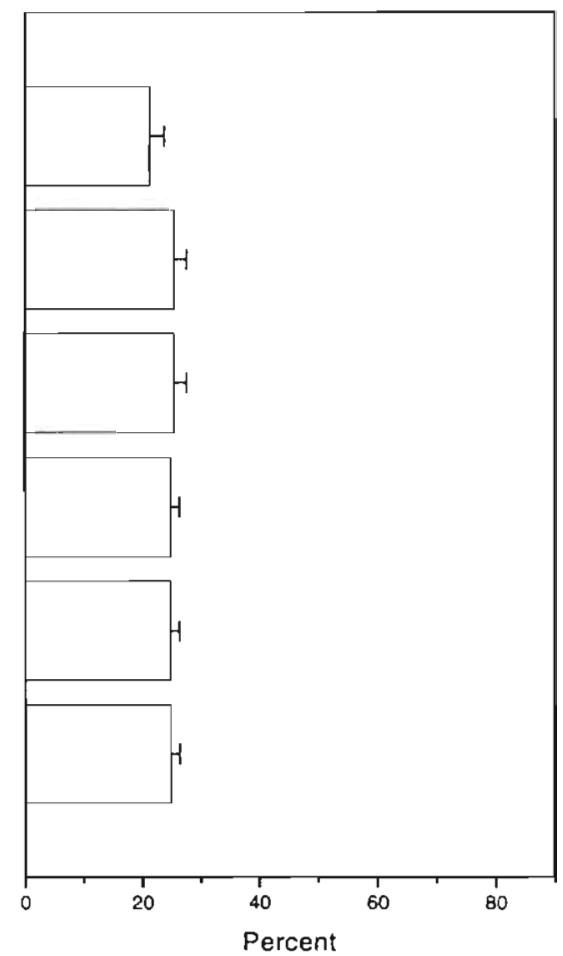

Fig. 3. Data for slurry incubations of lake sediments: percentage of $\mathrm{O}_{2}$ consumed by nitrification in (A) Lobelia-vegetated sediments and (C) bare sediments. Percentage of added $\mathrm{NO}_{3}{ }^{-}$denitrified in (B) Lobelia-vegetated sediments and (D) bare sediments 
tion. A very reduced sediment rich in organic material may increase competition for electron acceptors for both nitrifiers and denitrifiers and thus decrease the rhizosphere associated coupled nitrification-denitrification in proportion to a given $\mathrm{O}_{2}$ excretion over the roots.

Denitrification in the Lobelia dortmanna rhizosphere was estimated to be $24 \mu \mathrm{mol} \mathrm{N} \mathrm{m} \mathrm{N}^{-2} \mathrm{~h}^{-1}$ using the direct perfusion method. This corresponds well with the study of Risgaard-Petersen \& Jensen (1997), which indicates a rate $\left(D_{14}\right)$ of 10 to $15 \mu \mathrm{mol} \mathrm{N} \mathrm{m}^{-2} \mathrm{~h}^{-1}$, but is somewhat lower than the potential measurements indicated (97.2 $\left.\mu \mathrm{mol} \mathrm{N} \mathrm{m}^{-2} \mathrm{~h}^{-1}\right)$.

For Lobelia dortmanna the slurry method gave rates that were about 4 -fold higher than rates obtained from direct measurements ( 24 vs $93 \mu$ mol $\mathrm{N} \mathrm{m}^{-2} \mathrm{~h}^{-1}$ ). A probable reason for this divergence could be that the Lobelia plants in the present study were incubated at lower light irradiance than the plants studied by Pedersen et al. (1995) (150 vs $400 \mu \mathrm{mol}$ photons $\mathrm{m}^{-2} \mathrm{~s}^{-1}$ ), from which we used $\mathrm{O}_{2}$ release values.

Results obtained in this study indicate that the rhizosphere of eelgrass, in the investigated sediments, was a poor environment for nitrifying and denitrifying bacteria, possibly due to the effect of high organic loading to the sediment induced by the plants (Hemminga et al. 1991), or high sulfate reduction activity (Holmer \& Nielsen 1997, Blåberg et al. 1998), which are both known to impede nitrification (Henriksen \& Kemp 1988, Sloth et al. 1995).

The findings from this study emphasize the ecological differences between an isoetid-populated oligotrophic freshwater sediment and a seagrass-vegetated marine sediment rich in organic matter. The difference

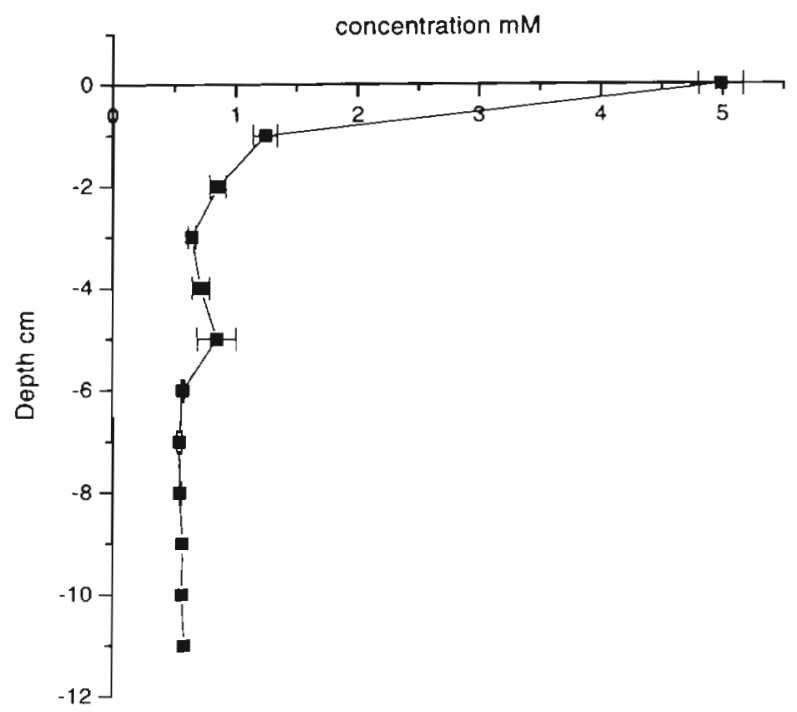

Fig. 4. Bromide profile in sediment core with a bromideenriched water column in ability to promote coupled nitrification-denitrification in the rhizosphere should be found both in the physiology of the plants and the habitat in which they grow. Isoetides investigated in this study grow in sediment with little reducing capacity and excrete nearly all photosynthetically produced $\mathrm{O}_{2}$ through the roots as they possess an extensive and continuous air lacuna

A. Eelgrass sediment, perfusion method

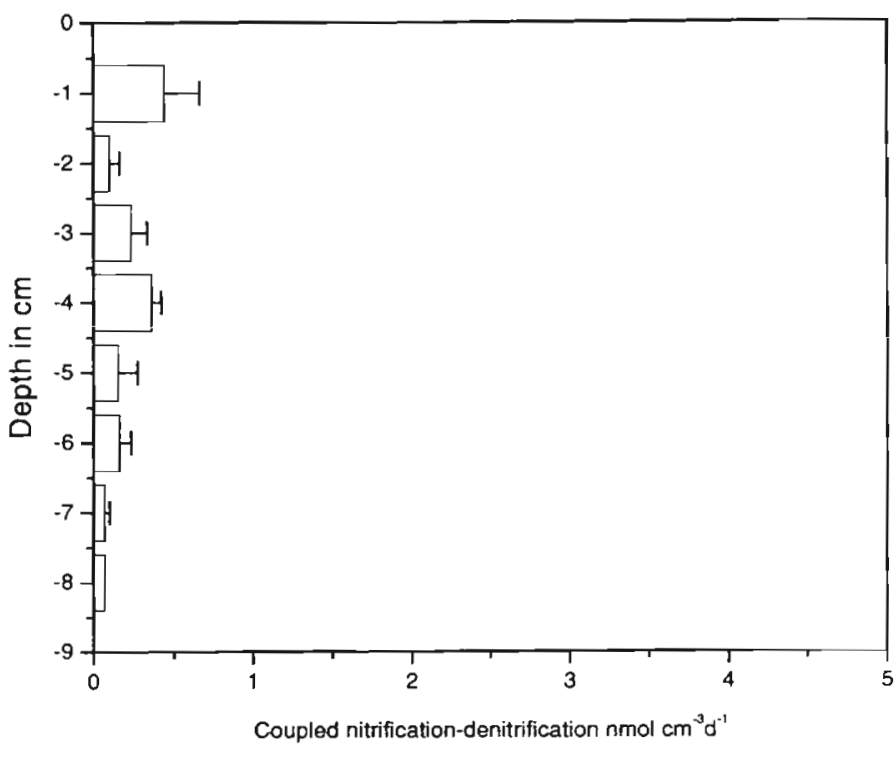

B. Bare marine sediment, perfusion method

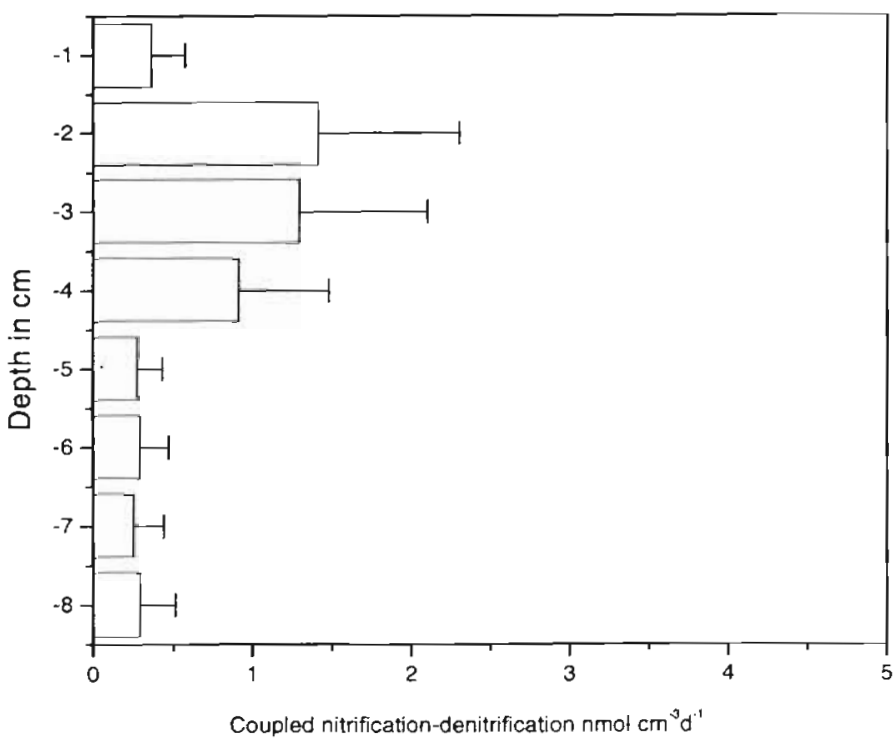

Fig. 5. Perfusion measurements of marine sediments. Coupled nitrification-denitrification in the rhizosphere of: (A) eelgrass (Zostera marina)-vegetated sediments and (B) bare sediments. Rates are in nmol $\mathrm{cm}^{3} \mathrm{~d}^{-1}$, given a diurnal cycle of $12 \mathrm{~h} \mathrm{light/dark}$ 
system and roots with a much higher gas permeability than leaves (SandJensen et al. 1982). It has been hypothesized that this adaptation primarily enables the plants to utilize $\mathrm{CO}_{2}$ of the porewater to supplement $\mathrm{CO}_{2}$ assimilated from the water, as $\mathrm{CO}_{2}$ concentration in the water is often very low in soft water oligotrophic lakes (Sand-Jensen \& Sondergaard 1979). Such plants thus oxidize a large fraction of the sediment (WiumAndersen \& Andersen 1972) and, besides facilitation of $\mathrm{CO}_{2}$ uptake over the roots, stimulate rhizosphere associated coupled nitrification-denitrification. Zostera marina, on the other hand, is inefficient in stimulating coupled nitrification-denitrification because it excretes little $\mathrm{O}_{2}$ through the roots (about $1 \%$ of photosynthetically produced $\mathrm{O}_{2}$ ), and often grows in a reducing sediment with high potential $\mathrm{O}_{2}$ consumption, leaving little $\mathrm{O}_{2}$ and $\mathrm{NO}_{3}{ }^{-}$to promote coupled nitrificationdenitrification. Unpublished $\mathrm{O}_{2}$ microsensor studies in the rhizosphere of Z. marina have shown an absence of $\mathrm{O}_{2}$ among the roots (Revsbech pers. comm., Risgaard-Petersen, Rysgaard \& Ottosen unpubl. data), indicating a low ability of $Z$. marina to oxidize the sediment. This study therefore underlines that coupled nitrification-denitrification in the rhizosphere should not be considered an important contribution to nitrogen cycling in Z. marina vegetated sediments, whereas it may have some significance in isoetid-populated sediments in oligotrophic lakes (Fig. 7).

We believe that the methods presented in this study are usable. The slurry incubations described in this study represent a new, more realistic, approach towards quantification of

Fig. 6. Perfusion measurements of lake sediments. Coupled nitrification-denitrification in the rhizosphere of: (A) Littorella uniflora-vegetated sediments, (B) Lobelia dortmanna-vegetated sediments, (C) Potamogeton perfoliatus-sediment and (D) bare sediments. Rates are in $\mathrm{nmol} \mathrm{cm} \mathrm{cm}^{-3} \mathrm{~d}^{-1}$, given a diurnal cycle of $12 \mathrm{~h}$ light/dark
A. Littorella sediment, perfusion method

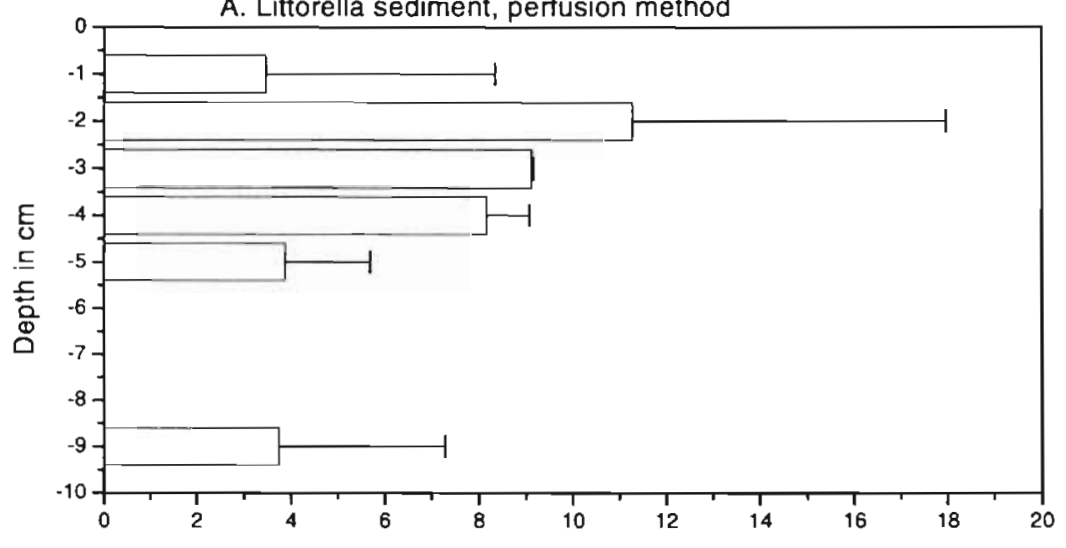

B. Lobelia sediment, perfusion method

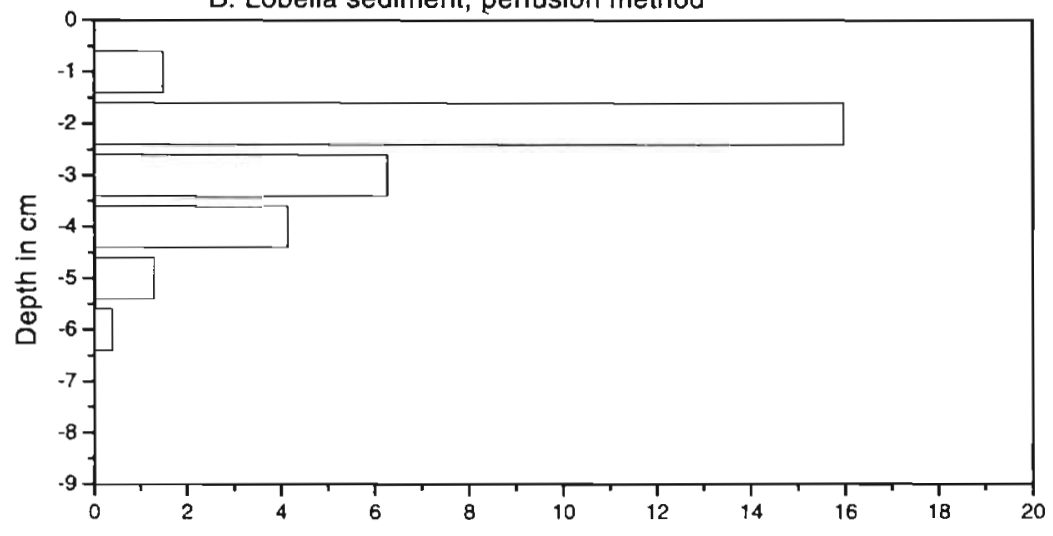

C. Potamogeton sediment, perfusion method
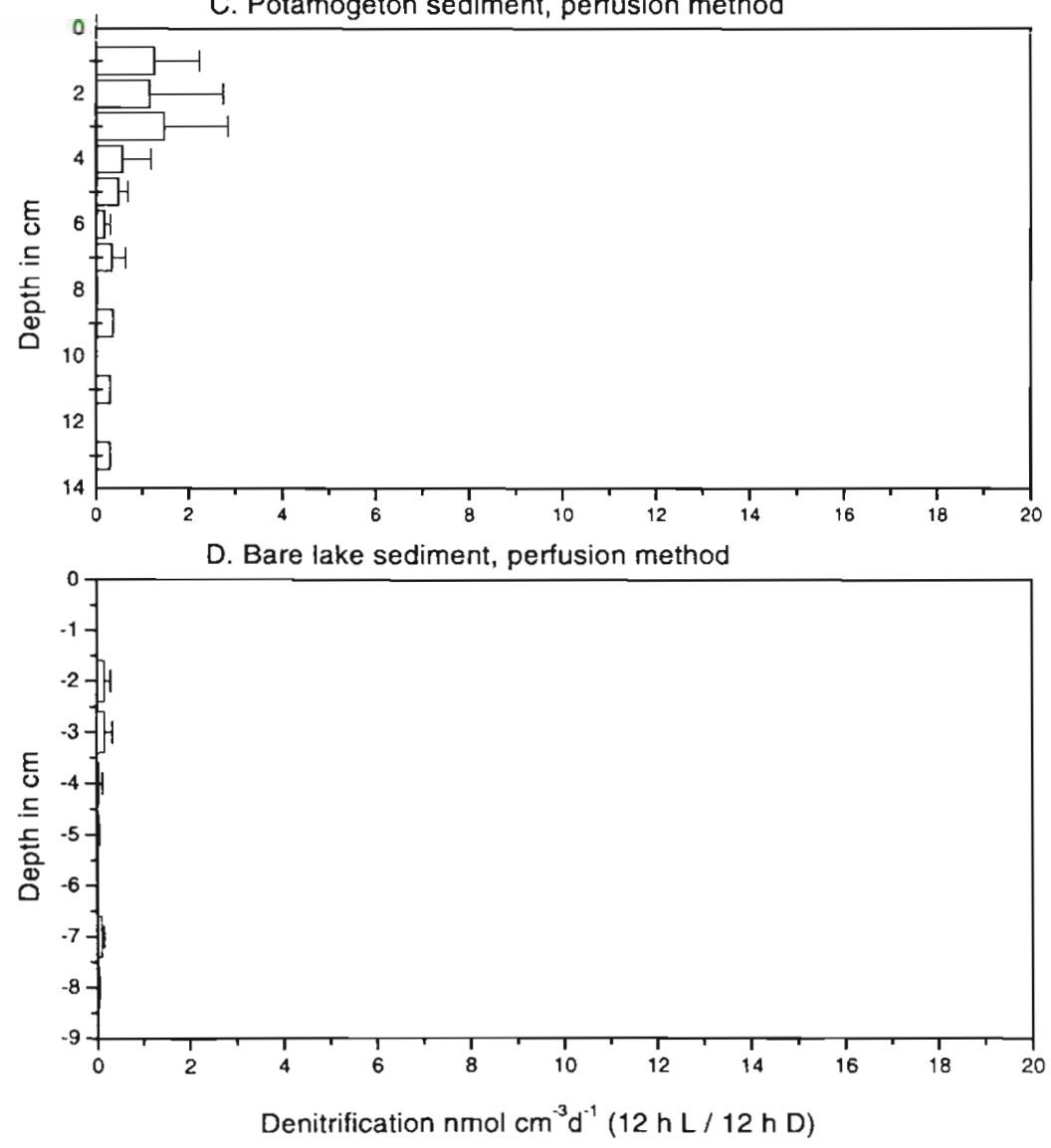


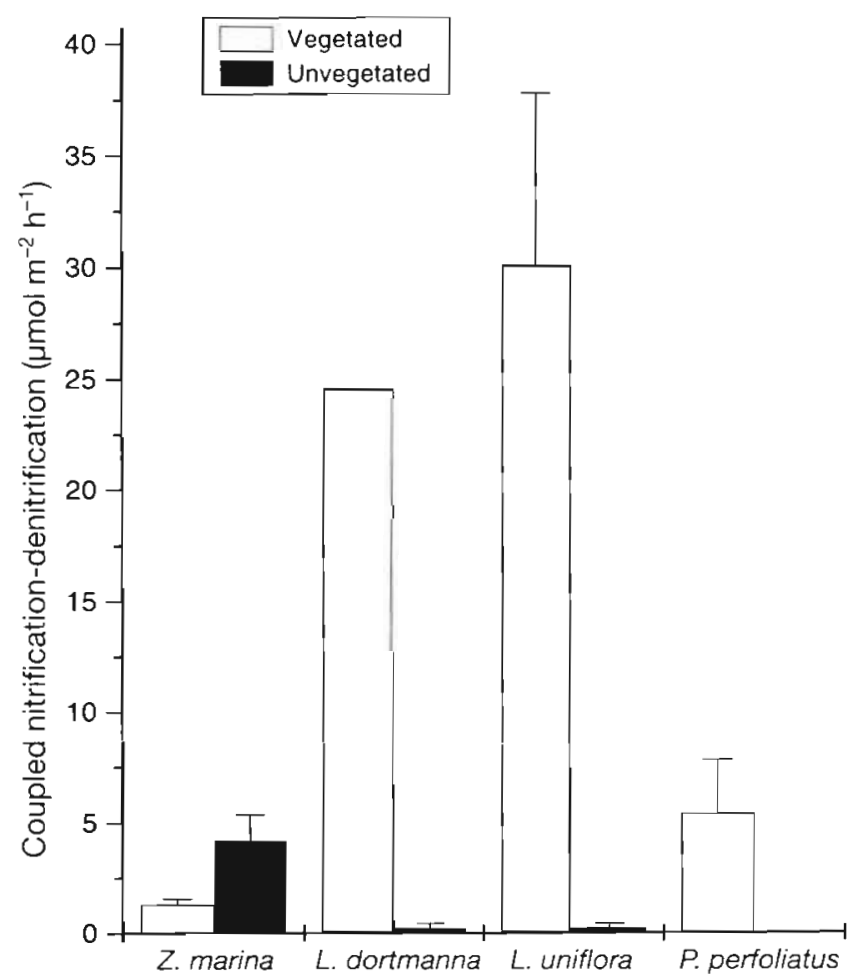

Fig. 7. Depth integrated coupled nitrification-denitrification activity in vegetated and unvegetated sediments studied with the perfusion technique

nitrification and denitrification, compared to traditional potential incubation procedures, as the rate measurements are linked to the consumption of $\mathrm{O}_{2}$. For the perfusion method, we believe this is the most direct and less destructive method presented hitherto to measure coupled nitrification-denitrification in the rhizosphere of intact plant-sediment systems. The difference between results obtained with freshwater plants in the perfusion experiments and potential incubations are likely to be caused by difference in light regime. However, the results for the Lobelia dortmanna and Littorella uniflora experiments can be taken as evidence that these methods are capable of detecting rhizosphere denitrification. From this study we conclude that the rooted freshwater plants $L$, dortmanna and $L$. uniflora clearly stimulate coupled nitrification-denitrification in the rhizosphere, whereas we could not show any significant coupled nitrification-denitrification in the rhizosphere of the eelgrass Zostera marina, and thereby demonstrate findings from other studies mentioned in the discussion.

Acknowledgements. Sten P. Andersen and Preben Sorensen provided valuable technical and field assistance. This work is a contribution to the European Union ELOISE (European
Land-Ocean Interaction Studies) program (ELOISE publication no. 107) in the framework of the NICE project carried out under contract no. MAS3-CT96-0048

\section{LITERATURE CITED}

Blåbjerg V, Mouritzen KN, Finster K (1998) Diel cycles of sulphate reduction rates in sediments of a Zostera marina bed (Dennark). Aquat Microb Ecol 15:97-102

Boast CW, Mulvaney RL, Baveye P (1988) Evaluation of nitrogen-15 tracer techniques for direct measurement of denitrification in soil: I. Theory. Soil Sci Soc Am J 52(5): $1317-1322$

Boon PI, Moriarty DJW, Saffigna G (1986) Nitrate metabolism in sediments from seagrass (Zostera capricorni) beds of Moreton bay, Australia. Mar Biol 91:269-275

Caffrey, JM, Kemp WM (1990) Nitrogen cycling in sediments with estuarine populations of Potamogeton perfoliatus and Zostera marina. Mar Ecol Prog Ser 66:147-160

Caffrey JM, Kemp WM (1991) Seasonal and spatial patterns of oxygen production, respiration and root rhizome release in Potamogeton perfoliatus and Zostera Manina. Aquat Bot 40:109-128

Christensen PB, Sørensen J (1986) Temporal variation of denitrification activity in plant-covered littoral sediment from Lake Hampen Denmark. Appl Environ Microbiol S1(6):1174-1179

Flindt MR (1994) Measurements of nutrient fluxes and mass balances by on-line in situ dialysis in a Zostera marina. bed culture. Verh Int Verein Limnol 25:2259-2264

Grasshoff K, Ehrhardt M, Kremling K (1983) Methods of seawater analysis. Verlag Chemie, Weinheim

Hemminga MA, Harrison PG, Van Lent F (1991) The balance of nutrient losses and gains in seagrass meadows. Mar Ecol Prog Ser 71:85-96

Henriksen K, Kemp WM (1988) Nitrification in estuarine and coastal marine sediments: methods patterns and regulating factors. In: Blackburn TH, Sørensen J (eds) Nitrogen cycling in coastal marine environments. John Wiley and Sons, New York, p 207-250

Holmer M, Nielsen SL (1997) Sediment sulfur dynamics related to biomass-density in Zostera marina (eelgrass) beds. Mar Ecol Prog Ser 146:163-171

Izumi H, Hattori A, McRoy CP (1980) Nitrate and nitrite in interstitial waters of eelgrass beds in relation to the rhizosphere. J Exp Mar Biol Ecol 47:191-201

Nielsen LP (1992) Denitrification in sediments determined from nitrogen isotope pairing. Microb Ecol 86:357-366

Pedersen O, Sand-Jensen $K_{1}$ Revsbech NP (1995) Diel pulses of $\mathrm{O}_{2}$ and $\mathrm{CO}_{2}$ in sandy lake sediments inhabited by Lobelia dortmanna. Ecology 76(5):1536-1545

Reddy KR, Patrick WH, Lindau CW (1989) Nitrificationdenitrification at the plant root interface in wetlands. Limnol Oceanogr 34(6):1004-1013

Risgaard-Petersen N, Jensen K (1997) Nitrification and denitrification in the rhizosphere of the aquatic macrophyte Lobelia dortmanna L. Limnol Oceanogr 42(3):529-537

Risgaard-Petersen N, Rysgaard S (1995) Nitrate reduction in sedimants and waterlogged soil measured by ${ }^{15} \mathrm{~N}$ techniques. In: Alef $K$, Nannipieri P (eds) Methods in applied soil microbiology and biochemistry. Academic Press Inc. London, p 287-295

Risgaard-Petersen N, Dalsgaard T, Rysgaard S, Christensen PB, Borum J, McGlathery K, Nielsen LP (1998) Nitrogen balance or a temprate eelgrass Zostera marinas bed. Mar Ecol Prog Ser 174:281-291 
Sand-Jensen K (1975) Biomass, net production and growth of eelgrass (Zostera marina L.) population in Vellerup Vig. Denmark. Ophelia 14:185-201

Sand-Jensen K, Sondergaard M (1979) Distribution and quantitative development of aquatic macrophytes in relation to sediment characteristics in oligotrophic Lake Kalgaard, Denmark. Freshw Biol 9:1-11

Sand-Jensen K, Prahl C, Stockholm H (1982) Oxygen release from roots of submerged aquatic macrophytes. Oikos 38: 349-354

Schriver P, Bøgestrand J, Jeppesen E, Sondergaard M (1995) Impact of submerged macrophytes on fish-zooplankton-

Editorial responsibility: Gary King:

Walpole, Maine, USA phytoplankton interactions: large-scale enclosure experiments in a shallow eutrophic lake. Freshw Biol 33:255-270

Sloth NP, Blackburn H, Hansen LS, Risgaard-Petersen N, Lornstein BAa (1995) Nitrogen cycling in sediments with different organic loading. Mar Ecol Prog Ser 116:163-170

Tiedje JM, Sexstone AJ, Myrold DD, Robinson JA (1982) Denitrification: ecological niches, competition and survival. Antonie Leeuwenhoek J Microbiol Serol 48:569-583

Wium-Andersen S, Andersen JM (1972) The influence of vegetation on the redox profile of the sediment of Grane Langesø a Danish Lobelia lake. Limnol Oceanogr 17: $948-952$

Submitted: October 28, 1998; Accepted: February 26, 1999 Proofs received from author(s): August 20, 1999 